Економічні науки: збірник наукових прачь Луиького національного технічного університету. Серія "Регіональна економіка". Випуск 17 (67). Редкол.: відп. ред. к.е.н., професор І.В. Кривов’язюк. Луцьк: ІВВ Луцького НТУ, 2020. 348 с.

УДК 339.168.5(477.82)

Дзюбинський А.В., к.е.н., доцент

Пахолюк О.В., к.т.н., доцент

Кравчук П.Я., к.е.н., доцент

Луцький національний технічний університет

\title{
ТРАНЗИТНИЙ ПОТЕНЦІАЛ ВОЛИНІ ПРИ ЗДІЙСНЕННІ МИТНО-ЛОГІСТИЧНИХ ОПЕРАЦІЙ
}

Стаття присвячена проблемам митної логістики. Зокрема досліджується вплив транспортної інфраструктури на транзитний потенціал регіону при здійснення митно-логістичних операцій. Також оцінюється митна інфраструктура, та її роль при експортно-імпортних операціях.

Ключові слова: митна логістика, транспорт, транспортний коридор, пункт пропуску, митний пост.

\section{Dziubynskyi A., Pakholiuk O., Kravchuk P. \\ TRANSIT POTENTIAL OF VOLYN DURING CUSTOMS AND LOGISTICS OPERATIONS}

When planning the functioning of the subject of foreign economic activity should take into account a number of factors affecting the logistics of goods across the customs border of Ukraine. It's relevant to optimize material, financial and information flows to understand where, when and how to document and move goods, technologies of declaration objects delivery to customs control points for the purpose of acceleration of cargoes movement; movement of goods across the customs border of Ukraine depending on the regimes applied to them. That is, the availability and level of development of infrastructure facilities, such as roads, railways, customs posts and checkpoints across the state border in customs and logistics operations are perhaps the most important.

The location of the Volyn Oblast in the border area requires not only taking into account the factor of checkpoints in the assessment of transit potential, but also the use of geographical location in order to bring the existing elements of the transport network to international standards requirements.

It is necessary to carry out reconstructions of the motor transport complex to increase the pace of socio-economic development. According to the State Program, reconstruction of the international highways of the Volyn Oblast under the first technical category is provided. Bringing the motor transport complex of Volyn to international parameters will perform a stimulating function for the transit potential of the oblast. 
Економічні науки: збірник наукових прачь Луиького національного технічного університету. Серія "Регіональна економіка". Випуск 17 (67). Редкол.: відп. ред. к.е.н., професор І.В. Кривов’язюк. Луцьк: ІВВ Луцького НТУ, 2020. 348 с.

Large traffic flows lead to significant problems in the work of Customs: the accumulation of vehicles in lanes and as a consequence them blocking. The Yahodyn and Ustyluh checkpoints need urgent modernization to increase capacity, reduce queues and improve service. Another option to solve the problem of the queue is to open a new checkpoint for freight transport, which is already being negotiated with the Polish side, Ambukiv-Hrudek - near the Izov railway checkpoint and the Ustyluh-Rivne highway.

Key words: customs logistics, transport, transport corridor, checkpoint, customs post.

\section{Дзюбинский А.В., Пахолюк Е.В., Кравчук П.Я. \\ ТРАНЗИТНЫЙ ПОТЕНЦИАЛ ВОЛЫНИ ПРИ ОСУЩИСТВЛЕНИИ ТАМОЖЕННО-ЛОГИСТИЧЕСКИХ ОПЕРАЦИЙ}

Статья посвящена проблемам таможенной логистики. В частности исследуется влияние транспортной инфраструктуры на транзитный потенциал региона при осуществлении таможенно-логистических операций. Также оценивается таможенная инфраструктура, и ее роль при экспортно-импортных операциях.

Ключевые слова: таможенная логистика, транспорт, транспортный коридор, пункт пропуска, таможенный пост.

\section{Постановка проблеми у загальному вигляді та ії зв'язок 3} важливими науковими та практичними завданнями. При плануванні діяльності суб'єктом ЗЕД мають враховувати ряд чинників, що впливають на логістику товарів через митний кордон України. Зокрема актуальності набувають питання оптимізації: матеріальних, фінансових та інформаційних потоків для розуміння того де, коли і як оформляти і переміщати товар; технології доставки об'єктів декларування до пунктів митного контролю $з$ метою прискорення руху вантажів; переміщення товарів через митний кордон України в залежності від режимів, які до них застосовуються. Тобто наявність та рівень розвитку інфраструктурних об'єктів, таких як доріг, залізничного сполучення, митних постів та пунктів пропуску через кордон при здійсненні митно-логістичних операцій $€$ чи не найважливішими. 
Економічні науки: збірник наукових прачь Луиького національного технічного університету. Серія "Регіональна економіка". Випуск 17 (67). Редкол.: відп. ред. к.е.н., професор І.В. Кривов'язюк. Луиьк: ІВВ Луцького НТУ, 2020. 348 с.

Аналіз останніх досліджень, у яких започатковано вирішення проблеми. Враховуючи поглиблення інтеграційних процесів 3 початку підписання першої частини угоди між Україною та ЄС 22 березня 2014 року та необхідності адаптації транспортних систем прикордонних територій до міжнародних норм корисними $є$ праці наступних зарубіжних вчених: А. Медісона, Д. Бенсона, Д. Молоні, Д. Коломбоса, П. Боше, У. Гроссмена.

Дослідженню питань митного регулювання в умовах глобалізації присвятили свої праці такі вчені, як Циганкова Т.М. [1], Яценко О.М. [2], Мазур А.В., Сорокін М.А. [3], Поланьі К.П. [4], Баласа Б. [5].

Цілі статті. Цілями написання статті $є$ дослідження впливу транспортної доступності та митної інфраструктури на транзитну привабливість Волині.

Виклад основного матеріалу дослідження 3 повним обгрунтуванням отриманих наукових результатів. Питання організації та забезпечення переміщення товарів через митний кордон України транспортною системою (ТС) - одне 3 ключових в митній логістиці. ТС включає транзитні перевезення, організацію залізничного сполучення, розвиток автомагістралей, повітряного, морського та річкового сполучення. В свою чергу наявністю транспортних вузлів різних рівнів та міжнародних автотранспортних коридорів (МАТК), пунктів пропуску та митних постів формують транзитний потенціал країни, чи окремого регіону.

Одним з основних факторів розвитку Волині вважається міжнародне співробітництво області через безпосереднє сусідство 3 Польщею (Хелмське і Замостське воєводства) та Білоруссю (Брестська область). Тому особлива увага останнім часом приділяєть розвитку транспортної інфраструктури регіону, як одного з головних чинників реалізації транзитного потенціалу. Приведення автомобільних доріг до вищих технічних категорій та побудова нових автотранспортних коридорів дає змогу використовувати території 3 більшим економічним навантаженням. Дієвою в цьому плані $є$ програма Великого 
Економічні науки: збірник наукових прачь Луиького національного технічного університету. Серія "Регіональна економіка". Випуск 17 (67). Редкол.: відп. ред. к.е.н., професор І.В. Кривов’язюк. Луцьк: ІВВ Луцького НТУ, 2020. 348 с.

будівництва, що не оминула і Волинь. Зокрема, планується відновлення, та приведення до міжнародних стандартів автошляху міжнародного значення М-19 Доманово (на м. Брест) - Ковель - Чернівці - Тереблече (на м.Бухарест).

Транспортна доступність $є$ одним 3 визначальних показників будь-яких економічних відносин та зв'язків, які можуть існувати в суспільстві, а також важливим елементом інвестиційної привабливості області. Головним критерієм, за допомогою якого визначають рівень розвитку транспортного сполучення, є його якість. Саме від типу покриття, кількості автошляхів (щільності), швидкості пересування по них, довжини мережі залежить пропускна здатність, або іншими словами доступність транспортного обслуговування для господарюючих суб'єктів, в тому числі і при здійсненні митно-логістичних операцій.

Автотранспортна система Волинської області складається 3 автошляхів державного (міжнародного, національного, регіонального) та місцевого (територіального, обласного, районного) значення (рисунок 1 ).

При плануванні митної логістики визначальними є віддалі від магістральних шляхів сполучення до економічних об'єктів , що впливає на планування витрат часу на переміщення товарів та людей дорогами різних категорій з відповідною інтенсивністю руху. Однак при оцінюванні транзитної привабливості області мають враховуватися не тільки щільність і віддаленість доріг, але й технічні характеристики (категорія (табл.1), пропускна здатність, середньодобова інтенсивність руху і т. д.), наявність населених пунктів через, які проходять автодороги, природні (погодні) умови, тобто усі чинники, що визначають швидкість та якість переміщення товарів до чи від митного кордону нашої країни. 
Економічні науки: збірник наукових пращь Луцького національного технічного університету. Серія "Регіональна економіка". Випуск 17 (67). Редкол.: відп. ред. к.е.н., професор І.В. Кривов’язюк. Луцьк: ІВВ Луцького НТУ, 2020. 348 с.

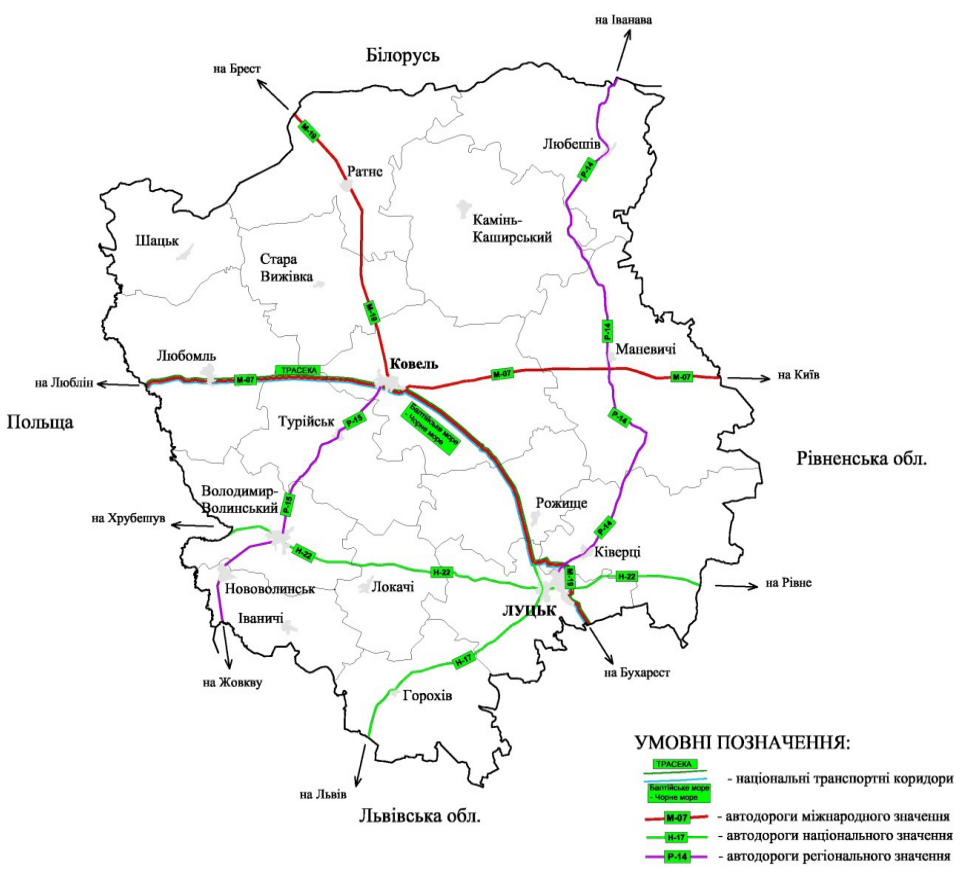

Рис. 1. Схема АТК на території Волинської області

Таблиця 1

Розрахункова швидкість руху

\begin{tabular}{|l|c|c|c|c|c|c|}
\hline Категорія дороги & I-a & I-б & II & III & IV & V \\
\hline $\begin{array}{l}\text { Розрахункова швидкість } \\
\text { руху, км/год }\end{array}$ & 120 & 110 & 100 & 80 & 60 & 40 \\
\hline
\end{tabular}

За даними Служби автомобільних доріг у Волинській області середня категорійність автомобільних доріг державного значення в межах області складає: для автодоріг міжнародного значення - 2,3, для автодоріг національного значення - 1,95, для автодоріг регіонального значення - 2,3, для автодоріг територіального значення - 3,5. 
Економічні науки: збірник наукових прачь Луиького національного технічного університету. Серія "Регіональна економіка". Випуск 17 (67). Редкол.: відп. ред. к.е.н., професор І.В. Кривов’язюк. Луцьк: ІВВ Луцького НТУ, 2020. 348 с.

Вплив цих чинників можна представити наступним виразом:

$$
F_{T}=f\left(\mathrm{x}_{1}, \mathrm{x}_{2}, \mathrm{x}_{3}, \mathrm{x}_{4}, \mathrm{x}_{5}\right),
$$

де $F_{T}$ - значення показника доступності;

$\mathrm{x}_{1}$ - щільність автомобільних доріг у регіоні;

$\mathrm{x}_{2}$ - віддаленість від а/д державного значення;

$\mathrm{x}_{3}$ - категорія автомобільної дороги;

$\mathrm{x}_{4}$ - кількість населених пунктів, у яких діє обмеження швидкості руху;

$\mathrm{X}_{5}$ - кількість днів 3 несприятливими погодніми умовами.

Стосовно залізничного сполучення, то Волинь, як i Україна має досить високий рівень забезпеченості залізницями, відстаючи від Польщі, Франції і Німеччини, але входить до першої десятки. Однак значною перепоною для інтенсифікації перевезень залізничним транспортом з країнами Східної Європи стає неоднакові технічні характеристики колій. Це пов'язано 3 шириною залізничної колії в Україні, яка становить 1,520 м та в європейських країнах - 1,435 м. На західному кордоні країни (в тому числі і на Волині) функціонує 14 спеціально обладнаних станцій та 8 пунктів перестановки вагонів на євроколію. Така „процедура" збільшує час знаходження товару в дорозі та нерідко є однією з причин відмови користуватись залізничним транспортом при здійсненні експортно-імпортних операцій.

Важливою компонентою транзитного потенціалу звичайно $є$ i наявність пунктів пропуску та митних постів. Територія області нараховує тринадцять пунктів пропуску (табл. 2). 
Економічні науки: збірник наукових прачь Луиького національного технічного університету. Серія "Регіональна економіка". Випуск 17 (67). Редкол.: відп. ред. к.е.н., професор І.В. Кривов’язюк. Луцьк: ІВВ Луцького НТУ, 2020. 348 с.

Таблиця 2

Пункти пропуску через державний кордон України у

Волинській області

\begin{tabular}{|c|c|c|c|c|c|}
\hline $\begin{array}{l}\text { № } \\
\text { п/п }\end{array}$ & $\begin{array}{c}\text { Назва пункту } \\
\text { пропуску/пункту } \\
\text { контролю }\end{array}$ & $\begin{array}{c}\text { Вид } \\
\text { пропуску }\end{array}$ & $\begin{array}{c}\text { Категорія } \\
\text { пункту } \\
\text { пропуску }\end{array}$ & $\begin{array}{c}\text { Характ. } \\
\text { перевезень }\end{array}$ & Район \\
\hline \multicolumn{6}{|c|}{ На кордоні з республікою Польща } \\
\hline 1 & Ягодин & A & M & П/В & \multirow{2}{*}{ Любомльський } \\
\hline 2 & Ягодин & 3 & M & П/В & \\
\hline 3 & Устилуг & A & $\mathrm{M}$ & $\Pi$ & \multirow[b]{2}{*}{$\begin{array}{l}\text { Володимир- } \\
\text { Волинський }\end{array}$} \\
\hline & $\begin{array}{l}\text { Володимир- } \\
\text { Волинський }\end{array}$ & 3 & M & П/В & \\
\hline \multicolumn{6}{|c|}{ На кордоні з республікою Білорусь } \\
\hline 5 & Дольск & A & M & $\mathrm{B} / \Pi$ & Любешівський \\
\hline 6 & Самари & A & Міждерж. & $\mathrm{B} / \Pi$ & \multirow{5}{*}{ Ратнівський } \\
\hline 7 & Доманове & A & $\mathrm{M}$ & $\mathrm{B} / \Pi$ & \\
\hline 8 & Тур & A & Місц. & $\Pi$ & \\
\hline 9 & Заболоття & 3 & $\mathrm{M}$ & $\mathrm{B} / \Pi$ & \\
\hline 10 & Гута & A & Місц. & $\Pi$ & \\
\hline 11 & Піща & A & Міждерж. & $\mathrm{B} / \Pi$ & \multirow{3}{*}{ Шацький } \\
\hline 12 & Хрипськ & A & Місц. & $\Pi$ & \\
\hline 13 & Пулемець & A & M & В/П & \\
\hline
\end{tabular}

Примітка 1: скорочені буквені позначення означають наступне: вид пропуску (А - автомобільний, 3 - залізничний), категорія пункту пропуску (М - міжнародний, Міждерж. - міждержавний, Місц. - місцевий), характер перевезень (П - пасажирський, П/В - пасажирський та вантажний).

Станом на кінець 2019 року на кордонах з Свросоюзом в межах Волині функціонує два міжнародних автомобільних пункти пропуску (ПП), «Ягодин» та «Устилуг», а також два залізничних: «Ягодин» (вузька колія) та «ВолодимирВолинський (Ізов)». Мжнародний автомобільний ПП «Ягодин» $\epsilon$ візитівкою Волині та одним 3 найбільших на кордонах України. Його добова пропускна спроможність - близько 1000 вантажних транспортних засобів, що є значно більшим показником за сумарний усіх пунктів пропуску, що розміщені, наприклад, в сусідній Львівській області. Після останньої реконструкції (2011 року) в ПП є 26 смуг руху, що забезпечують функціонування «зеленого» $\mathrm{i}$ «червоного» коридорів. 
Економічні науки: збірник наукових прачь Луиького національного технічного університету. Серія "Регіональна економіка". Випуск 17 (67). Редкол.: відп. ред. к.е.н., професор І.В. Кривов'язюк. Луиьк: ІВВ Луцького НТУ, 2020. 348 с.

На майже 500 кілометрах ділянки кордону між Україною та Польщею функціонує 4 пункти пропуску залізничного сполучення, два 3 яких на Волині - «Ягодин» та «ВолодимирВолинський (Ізов)». При цьому залізничне сполучення «Ягодин-Дорогуськ» уже вузькоколійне, тобто співпадає 3 європейськими стандартами.

За статистичною інформацією, представлено Волинською обласною радою, за 9 місяців 2019 року через ПП для залізничного сполучення, що розташовані в області, пройшло 218030 залізничних вагонів, або майже $83 \%$ загальнодержавного показника, та 7423,99 тис. тон вантажів $85 \%$ відповідно. Показники Львівської митниці значно скромніші - $16,4 \%$ та $14,3 \%$.

Висновки. Розташування Волинської області в прикордонній зоні вимагає не тільки врахування чинника пунктів пропуску в оцінці транзитного потенціалу, а й використання географічного положення 3 метою приведення існуючих елементів транспортної мережі до міжнародних стандартів.

Для підвищення темпів соціально-економічного розвитку потрібно здійснювати реконструкції автотранспортного комплексу. Відповідно до Державної програми передбачена реконструкція міжнародних автомобільних доріг Волинської області під I технічну категорію. Доведення автотранспортного комплексу Волині до міжнародних параметрів виконає стимулюючу функцію і для транзитного потенціалу області.

Уже сьогодні великі транспортні потоки призводять до чималих проблем в роботі митниці: накопичення транспортних засобів на автомобільних смугах руху і як наслідок блокування самого руху. Пункти пропуску «Ягодин» та «Устилуг» потребують невідкладної модернізації для збільшення пропускної спроможності, зменшенні черг та поліпшенні якості обслуговування. Ще одним варіантом вирішення проблеми черг $\epsilon$ відкриття нового пункту пропуску для вантажного транспорту, про який уже йдуть переговори 3 польською стороною, 
Економічні науки: збірник наукових прачь Луиького національного технічного університету. Серія "Регіональна економіка". Випуск 17 (67). Редкол.: відп. ред. к.е.н., професор І.В. Кривов’язюк. Луцьк: ІВВ Луцького НТУ, 2020. 348 с.

\section{«Амбуків-Грудек - поблизу залізничного ПП Ізов та автошляху «Устилуг - Рівне».}

\section{Список бібліографічного опису}

1. Глобальна торгова система: розвиток інститутів, правил, інструментів СОТ : монографія. Т.М. Циганкова, А.О. Олефір, О.В. Фурсова та ін.; За ред. Т.М. Циганкова; Київський національний економічний університет. К. : КНЕУ, 2003. 660 c.

2. Trade policy as an instrument of economic development. Olha Yatsenko The international scientific and analytical, reviewed, printing and electronic journal of Paata Gugushvili Institute of Economics of Ivane Javakhishvili Tbilisi State University «Ekonomisti» Tbilisi, 2017. № 2. P. 55-71.

3. Сорокин М.А. Таможенное регулирование в XXI веке: противоречия и угрозы национальных систем. Вестник Адыгейского государственного университета. Серия 5: Экономика. 2013. №4(131). С. 10-14.

4. Поланьи К.П. Великая трансформация: Политические и экономические истоки нашего времени / СПб. :Алетейя, 2014. 312 с.

5. Баласса Б. Экономическая интеграция / Под ред. Дж. Итуэлла, М. Милчейта, П. Ньюмена: Пер. с англ. М.: ИНФРА М, 2004. 944 с.

6. Угода про асоціацію між Україною, 3 однієї сторони, та Європейським Союзом i його державамичленами, 3 іншої сторони [Електроннй ресурс]. - Режим доступу: http://zakon2.rada.gov.ua/laws/show/984 011.

7. Державна служба статистики. Статистична інформація. Зовнішньоекономічна діяльність. Експорт-імпорт окремих видів товарів за країнами світу [Електронний ресурс]. - Режим доступу: http://www.ukrstat.gov.ua/operativ/operativ2016/zd/e_iovt/arh_iovt.

\section{References}

1. Tsigankova, T.M., Olefir, A.O., Fursova O.V. and others. (2003), Globalna torgova sistema: rozvitok InstitutIv, pravil, InstrumentIv SOT : monografIya [Global Trade System: Development of Institutions, Rules, Instruments of the WTO: Monograph]. Kyiv National Economic University. Kyiv, Ukraine.

2. Yatsenko, O. (2017), "Trade policy as an instrument of economic development". The international scientific and analytical, reviewed, printing and electronic journal of Paata Gugushvili Institute of Economics of Ivane Javakhishvili Tbilisi State University «Ekonomisti», vol. 2, pp. 55-71.

3. Sorokin, M.A. (2013), "Tamozhennoe regulirovanie v XXI veke: protivorechiya i ugrozyi natsionalnyih sistem" [Custom regulation in the XXI century: contradictions and threats of national systems] Bulletin of the Adygei State University. Series 5: Economics, vol. 4(131), pp. 10-14.

4. Polanyi, K.P. (2014), Velikaya transformatsiya: Politicheskie i ekonomicheskie istoki nashego vremeni [The Great Transformation: Political and Economic Origins of Our Time]. Ateleyya, St. Petersburg, Russia. 
Економічні науки: збірник наукових прачь Луиького національного технічного університету. Серія "Регіональна економіка". Випуск 17 (67). Редкол.: відп. ред. к.е.н., професор І.В. Кривов’язюк. Луцьк: ІВВ Луцького НТУ, 2020. 348 с.

5. Balassa, B. (2004), Ekonomicheskaya integratsiya [Economic integration] INFRA-M, Moscow, Russia.

6. Association Agreement between Ukraine, on the one hand, and the European Union and its member states, on the other hand (2015), available at: http://zakon2.rada.gov.ua/laws/show/984_011 (Accessed 10 Jan 2017).

7. State Statistics Service (2016). Statistical information. Foreign economic activity. Export-import of certain types of goods by countries of the world, available at: http://www.ukrstat.gov.ua/operativ/operativ2016/zd/e_iovt/arh_iovt (Accessed 10 Jan 2017). 